\title{
PENETAPAN DESA WIRAUSAHA DAN STRATEGI PENGEMBANGANNYA
}

\author{
Iman Hilman \\ Fakultas Ekonomi Universitas Pakuan \\ E-mail: iman_hilman23@yahoo.com
}

\begin{abstract}
Abstrak
Program desa wirausaha merupakan upaya untuk mengangkat potensi wilayah yang mampu menggerakkan perekonomian desa. Program ini juga bertujuan meningkatkan peran koperasi dan UKM di desa, menumbuhkan wirausaha baru, serta membuka lapangan kerja. Dalam kaitan itu, Pemerintah Kabupaten Bogor telah menetapkan Desa Gunung Malang Kecamatan Tenjolaya sebagai desa wirausaha. Kajian ini bertujuan untuk mengkaji metode penetapan desa wirausaha dan mengkaji apakah Desa Gunung Malang potensial sebagai desa wirausaha dan mengetahui strategi pengembangan desa wirausaha. Penelitian ini kemudian dilakukan dengan metode kualitatif dan kuantitatif. Responden dalam kajian ini adalah pelaku UKM dan pejabat pemerintah daerah. Penetapan desa wirausaha menggunakan 3 (tiga) pendekatan yaitu assesment potensi wilayah, keselarasan dengan harapan masyarakat dan kebijakan pemerintah. Dengan metode tersebut, Desa Gunung Malang memiliki potensi untuk dikembangkan sebagai desa wirausaha. Adapun strategi pengembangan desa wirausaha adalah peningkatan kualitas SDM, peningkatan kualitas alat produksi, pengembangan kelembagaan usaha, peningkatan kualitas aparatur desa, pengembangan promosi desa wirausaha, peningkatan kualitas infrastruktur, dan penyiapan masyarakat.
\end{abstract}

Kata Kunci: Desa Wirausaha, Metode Penetapan, Strategi Pengembangan

\begin{abstract}
Entrepreneurial village program is an effort to raise the potential of a region that can be a driver of village economic activities. The program also aims to increase the role of cooperatives and SMEs in villages, grow new entrepreneurs, and create employment opportunities. Therefore, the Government of Bogor Regency has established the Village of Gunung Malang, Tenjolaya as an entrepreneurial village. This study aims to examine the method of determining entrepreneurial villages and to examine whether the village of Gunung Malang is potential as an entrepreneurial village and to know the strategies in the development of entrepreneurial villages. This study was done by qualitative and quantitative methods. Respondents in this study were SMEs and local government officials. Establishment of entrepreneurial villages using 3 (three) approaches: the potential assessment of the region, alignment with community expectations and government policies. With these methods, Gunung Malang Village has the potential to be considered as an entrepreneurial village. Strategies needed for the development of entrepreneurial villages are improving the quality of human resources, improving the quality of production equipment, developing business institutions, improving the quality of rural apparatus, promoting entrepreneurial villages, improving the quality of infrastructure, and community preparation.
\end{abstract}

Keywords: Entrepreneurial Village, Method of the Establishment, Strategies of Development of Enterepreneurial Village 


\section{PENDAHULUAN}

Gagasan melahirkan desa wirausaha merupakan keinginan untuk mengangkat potensi dan keunggulan suatu wilayah yang mampu menjadi penggerak kegiatan perekonomian yang berdampak lebih luas. Karakteristik yang merupakan penarik dan pendorong sehingga tercipta desa wirausaha memiliki dimensi yang luas melampaui batasbatas potensi sektoral. Artinya penciptaan nilai tambah dari potensi dasar (mentah) terjadi di desa wirausaha ini.

Desa wirausaha tidak merupakan kampung atau kawasan yang dibatasi oleh administrasi, namun merupakan kawasan yang memiliki fungsi dan orientasi yang serupa. Desa wirausaha juga akan berhimpit dengan wilayah-wilayah lainnya yang diposisikan untuk berinteraksi secara menguntungkan (bersinergis). Sinergitas dapat bersifat ke hulu atau ke hilir. Pengembangan desa wirausaha juga bertujuan meningkatkan peran koperasi dan UKM di desa, menumbuhkan wirausaha baru, meningkatkan kegiatan ekonomi yang dapat meningkatkan nilai tambah serta membuka lapangan kerja.

Penetapan suatu desa wirausaha harus melalui assesment terhadap potensi wilayah, kondisi masyarakat, sarana dan prasarana, keterkaitan aktivitas ekonomi dengan wilayah-wilayah lainnya, aspek pendukung seperti kelembagaan keuangan, posisi geografis yang diuntungkan serta resultante keseluruhannya. Posisi yang diuntungkan maksudnya posisi yang strategis, seperti jalur/lintasan yang menghubungkan suatu wilayah potensial dengan wilayah potensial lainnya. Keuntungan tersebut dapat tergambarkan dari mudahnya memasarkan produk-produk yang dihasilkan sebagai dampak dari dekatnya dengan wilayah pemasaran (wilayah dengan jumlah penduduk yang tinggi yang ditunjang oleh tingkat daya beli yang tinggi pula). Keuntungan yang lain adalah kemudahan mendapatkan bahan baku dan bahan pendukung lainnya sebagai dampak dari dekatnya dengan wilayah potensi bahan baku yang didukung sarana dan prasarana yang memadai, seperti akses jalan dan akses komunikasi. Hal yang juga sangat penting adalah munculnya kebanggaan dari masyarakat yang berdomisili di desa wirausaha tersebut.

Desa Gunung Malang yang berlokasi di Kecamatan Tenjolaya Kabupaten Bogor diproyeksikan sebagai salah satu desa yang akan menjadi percontohan desa wirausaha. Lokasinya yang berada di kawasan wisata Gunung Salak Endah dan akses jalan yang memadai dinilai berpotensi menjadi desa wirausaha.

Persoalannya adalah bagaimana metode penetapan desa wirausaha sehingga peluang keberhasilannya sebagai desa wirausaha lebih besar. Apakah Desa Gunung Malang benar-benar potensial menjadi desa wirausaha dan bagaimana strategi yang diperlukan untuk pengembangan desa wirausaha di Desa Gunung Malang tersebut.

\section{TINJAUAN PUSTAKA}

\section{Pengertian Kewirausahaan dan Wirausaha (Entrepreneur)}

Kewirausahaan secara umum diartikan sebagai proses mengerjakan sesuatu yang baru atau kreatif dan berbeda (inovatif) yang bermanfaat dalam memberikan nilai lebih. Menurut Joko Untoro (2010) kewirausahaan adalah suatu keberanian untuk melakukan upaya-upaya memenuhi kebutuhan hidup yang dilakukan oleh seseorang, atas dasar kemampuan dengan cara memanfaatkan potensi yang dimiliki untuk menghasilkan sesuatu yang bermanfaat bagi dirinya dan orang lain. Ronald Melicher (2011) mengemukakan bahwa kewirausahaan adalah proses dalam merubah ide menjadi kesempatan komersil dan menciptakan nilai (harga). Adapun pengertian wirausahawan adalah orang yang menjalankan wirausaha. Berikut beberapa 
pengertian wirausahawan atau entrepreneur dari beberapa ahli:

1. Wirausahawan atau enterpreneur adalah orang yang memiliki kemampuan melihat dan menilai kesempatan-kesempatan bisnis, mengumpulkan sumber-sumber daya yang dibutuhkan untuk mengambil keuntungan daripadanya serta mengambil tindakan yang tepat untuk memastikan kesuksesan (Geoffrey, G. Meredit et al., 1996).

2. Pengertian Kewirausahaan menurut Drucker (1996) menyatakan bahwa kewirausahaan adalah suatu kemampuan dalam menciptakan sesuatu yang berbeda dan baru.

\section{Pengertian Desa Wirausaha}

Geliat perekonomian perdesaan seringkali dinilai lambat dibanding pembangunan ekonomi perkotaan. Penataan ekonomi perdesaan perlu segera dilakukan dengan memanfaatkan sumber daya desa secara optimal dengan cara yang sesuai dengan kondisi dan kebutuhan masyarakat dalam mencapai kesejahteraan secara menyeluruh dan berkelanjutan. Untuk mencapainya, diperlukan dua pendekatan yaitu: (a) Kebutuhan masyarakat dalam melakukan upaya perubahan dan mencegah hal-hal yang tidak diinginkan; dan (b) Political will dan kemampuan pemerintah desa bersama masyarakat dalam mengimplementasikan perencanaan pembangunan yang sudah disusun (Rustiadi, 2011).

Potensi sumber daya desa selama ini belum termanfaatkan secara optimal. Jika pun ada yang memanfaatkan, cenderung eksploitatif dan tidak mempertimbangkan dampak yang ditimbulkan akibat eksploitasi sumber daya desa. Salah satu solusi penting yang mampu mendorong gerak ekonomi desa adalah mengembangkan kewirausahaan bagi masyarakat desa. Pengembangan desa wirausaha menawarkan solusi untuk mengurangi kemiskinan, migrasi penduduk, dan pengembangan lapangan kerja di desa.

Pada Model Sistem Pembangunan Kewirausahaan Desa, pembangunan dilakukan dengan menggunakan Industri Desa sebagai driver penggerak berputarnya kegiatan ekonomi desa. Jika Industri Desa maju maka akan menarik usahausaha lainnya sehingga kegiatan perekonomian akan makin meningkat dan diharapkan dapat membawa ke peningkatan kesejahteraan masyarakat desa (Widjajani, 2015)

Apabila desa wirausaha menjadi suatu gerakan masif, maka merupakan hal yang sangat mungkin untuk mendorong perkembangan ekonomi perdesaan. Desa wirausaha merupakan program yang dapat dikembangkan untuk mengatasi pengangguran, pendapatan rendah, dan menambah keragaman jenis usaha di desa. Kewirausahaan masyarakat desa pun dapat bermakna mengorganisir struktur ekonomi perdesaan. Seluruh aset desa seperti tanah, air, lingkungan, dan tenaga kerja dapat menjadi modal pengembangan usaha baru yang digerakkan bersama-sama oleh seluruh elemen desa.

\section{METODE PENELITIAN}

Metode penelitian ini menggunakan 2 (dua) metode yaitu desk research dan field research. Metode desk research dilakukan untuk melakukan studi literatur dan mengumpulkan data sekunder. Studi literatur dilakukan untuk menelaah konsep-konsep desa wirausaha. Adapun data sekunder digunakan untuk menelaah data-data terkait wilayah Desa Gunung Malang. Selanjutnya field research dilakukan untuk mendapatkan data primer. Ada 2 (dua) teknik yang digunakan, yaitu wawancara dengan tokoh masyarakat Desa Gunung Malang. Wawancara tatap muka yang berpedoman pada kuesioner terstruktur dan dilakukan dengan 100 orang pelaku UKM di Desa Gunung Malang. Penelitian kemudian dilakukan di Desa Gunung Malang Kecamatan 
Tenjolaya Kabupaten Bogor pada periode September-Oktober 2017.

Kerangka pemikiran penellitian ini diawali dengan penentuan desa wirausaha yang memperhatikan potensi wilayah seperti posisi geografis, sumberdaya alam, sumberdaya manusia, infrastruktur penunjang dan jenis usaha yang sudah berkembang. Penentuan desa wirausaha juga mempertimbangkan harapan atau ekspektasi masyarakat dalam mengembangkan dirinya dan membangun wilayahnya, serta memperhatikan kendala yang selama ini dihadapi. Selanjutnya penentuan desa wirausaha juga harus sesuai dengan kebijakan pemerintah daerah terutama dalam pembangunan ekonomi dan pengembangan wilayah. Secara ringkas kerangka pemikiran penelitian ini dapat dilihat pada gambar sebagai berikut:

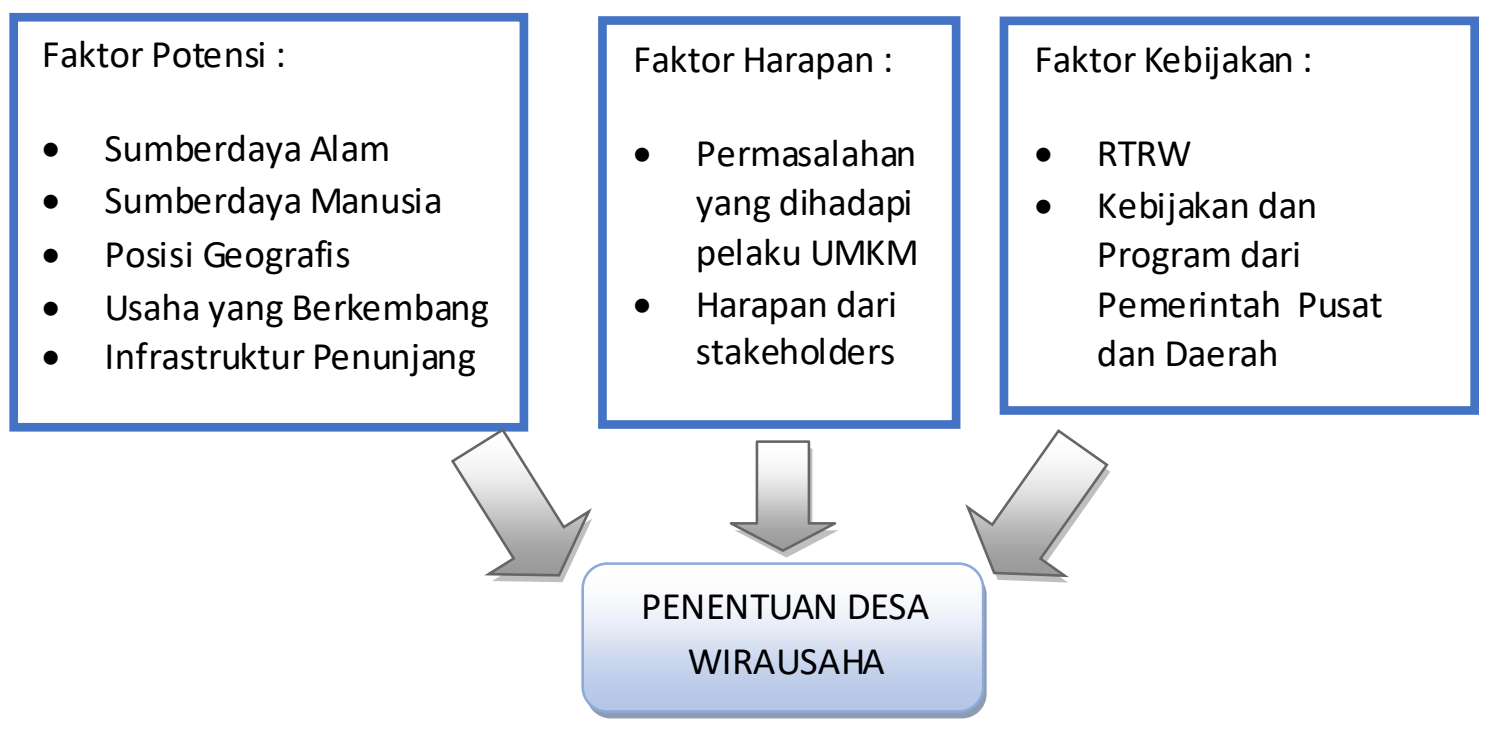

Gambar 1.

Kerangka Pemikiran

PEMBAHASAN

\section{Pengembangan Metode Penetapan Desa Wirausaha}

Berdasarkan kerangka pemikiran di atas, metode penetapan desa wirausaha mempertimbangkan 3 (tiga) faktor yaitu faktor potensi wilayah, faktor harapan masyarakat dan faktor kebijakan pemerintah. Untuk faktor potensi wilayah, dilakukan dengan assessment. Assessment ini dilakukan dengan menilai potensi sebuah wilayah berdasarkan beberapa parameter dan indikator yang relevan. Setiap parameter diberi bobot sesuai dengan perkiraan besarnya pengaruh atau kontribusi terhadap potensi wilayah. Adapun parameter, bobot, dan indikator dari setiap parameter, seta nilai untuk setiap indikator dapat dilihat pada tabel berikut ini: 
Tabel 1.

Faktor Penetapan Desa Wirausaha

\begin{tabular}{|c|c|c|c|c|}
\hline No & Parameter & Bobot & Indikator & Nilai \\
\hline \multirow[t]{2}{*}{1} & Posisi Geografis & $10 \%$ & Dekat dari ibukota kecamatan & 2 \\
\hline & & & Jauh dari ibokota kecamatan & 1 \\
\hline \multirow[t]{4}{*}{2} & Potensi Wilayah & $20 \%$ & $\begin{array}{l}\text { Memiliki potensi pada } 3 \text { sektor } \\
\text { (pertanian, peternakan, perikanan } \\
\text { dan pertambangan) }\end{array}$ & 4 \\
\hline & & & Memiliki potensi pada 3 sektor & 3 \\
\hline & & & Memiliki potensi pada 2 sektor & 2 \\
\hline & & & Memiliki potensi pada 1 sektor & 1 \\
\hline \multirow[t]{3}{*}{3} & Potensi SDM & $20 \%$ & $\begin{array}{l}\text { Tingkat pendidikan rata-rata } \\
\text { minimal SMA }\end{array}$ & 3 \\
\hline & & & $\begin{array}{l}\text { Tingkat pendidikan rata-rata } \\
\text { minimal SMP }\end{array}$ & 2 \\
\hline & & & $\begin{array}{l}\text { Tingkat pendidikan rata-rata } \\
\text { minimal SD }\end{array}$ & 1 \\
\hline \multirow[t]{7}{*}{4} & $\begin{array}{l}\text { Potensi Pengembangan UMKM } \\
\text { sektor pengolahan }\end{array}$ & $30 \%$ & Jumlah UMKM di atas 50 & 3 \\
\hline & & & Jumlah UMKM antara 20 hingga 50 & 2 \\
\hline & & & Jumlah UMKM kurang dari 20 & 1 \\
\hline & & & Bahan baku dari wilayah sendiri & 2 \\
\hline & & & Bahan baku dari luar wilayah & 1 \\
\hline & & & $\begin{array}{l}\text { Pemasaran ke luar wilayah } \\
\text { kecamatan }\end{array}$ & 2 \\
\hline & & & $\begin{array}{l}\text { Pemasaran masih di dalam } \\
\text { kecamatan }\end{array}$ & 1 \\
\hline \multirow[t]{10}{*}{5} & Infrastruktur Penunjang & $20 \%$ & Kondisi jalan baik & 2 \\
\hline & & & Kondisi jalan buruk & 1 \\
\hline & & & Dilalui trayek angkutan umum & 2 \\
\hline & & & Tidak ada angkutan umum & 1 \\
\hline & & & Listrik memadai & 2 \\
\hline & & & Listrik masih kurang & 1 \\
\hline & & & Memiliki sumber air bersih & 2 \\
\hline & & & Air bersih relatif sulit & 1 \\
\hline & & & Saluran seluler banyak & 2 \\
\hline & & & Saluran seluler terbatas & 1 \\
\hline
\end{tabular}

Untuk mengetahui harapan masyarakat, dilakukan dengan melakukan wawancara tatap muka dengan masyarakat, dalam hal ini adalah pelaku UKM. Namun sebelumnya harus ditentukan dulu jenis usaha dominan yang akan menjadi ikon dalam pengembangan desa wirausaha. Berdasarkan hasil wawancara mendalam dengan tokoh masyarakat dan penelusuran data sekunder diperoleh informasi bahwa jenis usaha yang cukup dominan dan berpotensi menjadi ikon desa wirausaha adalah kerajinan anyaman bambu dan produk dari bambu.
Adapun untuk faktor kebijakan adalah dengan mempelajari berbagai kebijakan dari kementeriam terkait dan dari pemerintah daerah. Kementerian terkait di antaranya Kementerian Koperasi dan UKM, Kementerian Desa, Transmigrasi dan Pembangunan Daerah Tertinggal, Kementerian Pariwisata dan lain-lain.

\section{Pengujian Penetapan Desa Gunung Malang sebagai Desa Wirausaha}

Dari hasil assessment dengan instrumen yang telah ditentukan, diperoleh kondisi Desa Gunung Malang sebagai berikut: 
Tabel 2.

Kondisi Desa Gunung Malang

\begin{tabular}{|c|c|c|c|c|c|}
\hline No & Parameter & Bobot & Indikator & Nilai & Skor \\
\hline 1 & Posisi Geografis & $10 \%$ & Dekat dari ibukota kecamatan & 2 & 0,2 \\
\hline 2 & Potensi Wilayah & $20 \%$ & $\begin{array}{l}\text { Memiliki potensi pada } 3 \text { sektor } \\
\text { (pertanian, peternakan, } \\
\text { perikanan) }\end{array}$ & 3 & 0,6 \\
\hline 3 & Potensi SDM & $20 \%$ & $\begin{array}{l}\text { Tingkat pendidikan rata-rata } \\
\text { minimal SMP }\end{array}$ & 2 & 0,4 \\
\hline \multirow[t]{3}{*}{4} & $\begin{array}{l}\text { Potensi Pengembangan } \\
\text { UMKM r sektor } \\
\text { pengolahan }\end{array}$ & $30 \%$ & Jumlah UMKM di atas 50 & 3 & 2,1 \\
\hline & & & $\begin{array}{l}\text { Bahan baku dari wilayah } \\
\text { sendiri }\end{array}$ & 2 & \\
\hline & & & $\begin{array}{l}\text { Pemasaran ke luar wilayah } \\
\text { kecamatan }\end{array}$ & 2 & \\
\hline \multirow[t]{6}{*}{5} & $\begin{array}{l}\text { Infrastruktur } \\
\text { Penunjang }\end{array}$ & $20 \%$ & Kondisi jalan baik & 2 & 2 \\
\hline & & & Dilalui trayek angkutan umum & 2 & \\
\hline & & & Listrik memadai & 2 & \\
\hline & & & Memiliki sumber air bersih & 2 & \\
\hline & & & Saluran seluler banyak & 2 & \\
\hline & Jumlah Skor & & & 23 & $\begin{array}{l}5,3 \text { dari } \\
\text { total } \\
\text { maksimum } \\
\text { skor } 5,7\end{array}$ \\
\hline
\end{tabular}

Dari tabel di atas dapat dilihat bahwa Desa Gunung Malang memenuhi persyaratan dan kriteria untuk pengembangan desa wirausaha, dengan nilai skor yang diperoleh sebesar 5,3 dari total maksimum skor 5,7. Aspek yang masih lemah dari penilaian adalah rata-rata tingkat pendidikan penduduk yaitu umumnya berpendidikan SMP. Sedangkan hal-hal yang menunjang tingginya nilai skor adalah banyaknya objek wisata yang berada di Desa Gunung Malang dan di desadesa sekitarnya. Hal ini menjadi peluang dalam mengembangkan berbagai kegiatan perdagangan dan jasa yang menunjang sektor pariwisata.

Dari hasil pengamatan di lapangan dan wawancara dengan aparat desa diperoleh informasi bahwa masyarakat Desa Gunung Malang cukup produktif dan kreatif. Selain sebagian besar menjadi petani, mereka umumnya juga mengembangkan produkproduk pengolahan walaupun masih dalam skala rumah tangga. Di antara beberapa usaha yang dikembangkan, ada dua jenis usaha yang cukup dominan yaitu produk pengolahan bambu seperti tusuk sate, boboko, tampah, bongsang, dan lain-lain, serta produk konveksi. Dari kedua jenis usaha UMKM yang dominan tersebut, masyarakat Desa Gunung Malang memutuskan untuk mengembangkan produk pengolahan bambu sebagai produk utama dalam program pengembangan Desa Wirausaha. Beberapa alasan yang menjadi dasar pertimbangan adalah:

1. Produk pengolahan bambu menggunakan bahan baku dari desa sendiri, sedangkan produk konveksi menggunakan bahan baku dari luar desa.

JIMFE (Jurnal Ilmiah Manajemen Fakultas Ekonomi)

Volume 3 No. 2 Tahun 2017, Hal. 28-36 
2. Produk pengolahan bambu menciptakan nilai tambah bagi hasil bambu di desa.

3. Masyarakat yang mengusahakan produk pengolahan bambu lebih banyak dibandingkan yang membuat produk konveksi.

4. Produk-produk pengolahan bambu merupakan hasil kreativitas masyarakat yang perlu terus dilestarikan dan dikembangkan.

5. Produk pengolahan bambu memiliki potensi untuk dikembangkan terutama jika mendapatkan sentuhan teknologi dan desain yang lebih marketable.

Saat ini, para pengrajin menghadapi beberapa kendala dalam pengembangan usaha, di antaranya adalah: harga jual yang masih rendah, teknik produksi yang masih tradisional, desain produk yang belum berkembang, kualitas SDM yang relatif rendah dan kendala pengembangan pasar. Berdasarkan kendala-kendala tersebut, masyarakat pelaku usaha dan aparatur wilayah berharap dengan adanya program desa wirausaha tersebut dapat mengembangkan usaha kerajinan bambu serta mampu mendorong motivasi generasi muda dalam meneruskan dan mengembangkan usaha yang yang telah dirintis orang tuanya.

Penetapan desa wirausaha di Desa Gunung Malang juga ternyata relevan dengan berbagai program dari kementerian/pemerintah daerah. Salah satunya adalah pengembangan Desa Gunung Malang sebagai desa wisata dan program pengembangan BUMDES dari Kementerian Desa.

\section{Strategi Pengembangan Desa Wirausaha di Desa Gunung Malang}

Penyusunan strategi pengembangan disusun berdasarkan potensi dan permasalahan yang dihadapi. Adapun strategi yang dapat dikembangkan adalah sebagai berikut:

\section{Peningkatan Kualitas SDM Pengrajin}

Para pengrajin pengolahan bambu umumnya masih berpendidikan rendah (SD) dan sebagian besar belum pernah menerima program pelatihan atau program peningkatan kualitas SDM lainnya. Oleh karena itu, strategi pertama yang perlu dilakukan adalah meningkatkan kualitas SDM pengrajin melalui program pelatihan. Adapun materi pelatihan yang perlu diberikan kepada para pengrajin idealnya meliputi 3 (tiga) aspek, yaitu: pengembangan mental entrepreneurship, pengembangan keterampian manajerial (soft skill) dan peningkatan keterampilan dalam menghasilkan produk yang inovatif (hard skill).

\section{Peningkatan Kualitas Alat Produksi}

Berkaitan dengan strategi pertama, maka perlu juga dikembangkan strategi kedua yaitu peningkatan kualitas alat produksi yang digunakan. Saat ini alat yang umumnya digunakan adalah golok, gergaji, pisau raut dan kihkir. Dari hasil wawancara diketahui bahwa umumnya mereka berharap adanya bantuan terhadap pengadaan alat kerja yang lebih memudahkan mereka menghasilkan poduk yang berkualitas. Jenis peralatan yang akan diberikan harus disesuaikan dengan produk yang akan dikembangkan.

\section{Pengembangan Kelembagaan Usaha}

Para pengrajin pengolahan bambu umumnya masih bekerja sendiri-sendiri, tidak berkelompok atau berkoperasi. Mereka juga masih memasarkan sendiri dengan akses yang terbatas dan tidak memiliki akses kepada sumber-sumber permodalan. Oleh karena itu, strategi ketiga yang diperlukan adalah pengembangan kelembagaan usaha. Ada dua alternatif bentuk kelembagaan yang dapat dikembangkan, yaitu:

a. Koperasi. Koperasi ini diharapkan beranggotakan semua pengrajin pengolahan bambu. Tujuan pembentukan koperasi ini adalah 
untuk menjadi tempat mereka menabung dan memperoleh permodalan, juga untuk menjadi lembaga yang dapat membantu pemasaran produk-produk hasil pengrajin. Koperasi dapat membuka outlet di beberapa obyek wisata terdekat dan bekerjasama dengan outlet-outlet yang menjual produk kerajinan.

b. BUMDES (Badan Usaha Milik Desa). Saat ini pemerintah tengah mendorong pendirian BUMDES untuk menjadi pelaku usaha ekonomi di desa. Oleh karena itu, program ini dapat disinergikan dengan program pemerintah tersebut. BUMDES dapat berperan terutama dalam memasarkan produk-produk hasil pengrajin dan mebantu akses permodalan melalui kerjasama dengan perbankan atau lembaga keuangan lainnya.

\section{Peningkatan Kapasitas Aparatur Desa}

Program pengembangan desa wirausaha kesuksesannya juga akan sangat tergantung kepada kapasitas aparatur desa. Oleh karena itu, perlu upaya sosialisasi tentang program ini dan peningkatkan kapasitas aparatur desa sehingga mampu menjadi mitra pemerintah daerah dalam mensukseskan program desa wirausaha.

5. Pengembangan Promosi Desa Wirausaha sebagai Desa Wisata

Program pengembangan desa wirausaha akan berhasil jika disinergikan dengan upaya pengembangan Desa Gunung Malang sebagai desa wisata. Oleh karena itu, perlu dibantu dengan strategi promosi yang tepat terutama kepada segmen wisatawan umum dan khusus. Promosi yang saat ini cukup efektif dijalankan adalah melalui pemanfaatan internet dan media sosial, seperti bekerjasama dengan para blogger, vlogger dan youtuber untuk mengekspose Desa Gunung Malang sebagai desa wisata. Promosi juga dapat dilaksanakan dengan mengadakan event di Desa Gunung Malang.

\section{Peningkatan Kualitas Infrastruktur}

Program pengembangan desa wirausaha akan berhasil jika didukung oleh infrastruktur yang memadai terutama jalan. Saat ini secara kualitas, jalan menuju Kecamatan Tenjolaya khususnya Desa Gunung Malang sudah memadai, namun yang masih kurang adalah lebar jalan. Padahal Kecamatan Tenjolaya memiliki potensi yang bagus sebagai destinasi wisata alternatif dari kawasan Puncak yang sudah padat. Oleh karena itu, perlu dilakukan pelebaran jalan untuk meningkatkan aksesibilitas para wisatawan.

\section{Penyiapan Masyarakat}

Program pengembangan desa wirausaha perlu didukung oleh kesiapan masyarakat, terutama sikap dan mental masyarakat yang senang dengan kegiatan wirausaha. Aspek lain yang perlu dikembangkan adalah masyarakat yang sadar wisata sehingga siap menjadi pelayan yang baik bagi para wisatawan. Strategi ini dapat dijalankan melalui program sosialisasi, pelatihan kewirausahaan bagi para pemuda desa, pelibatan tokoh-tokoh masyarakat dan mengintegrasikan program pengembangan desa wirausaha dan desa wisata dalam program pembangunan desa.

\section{PENUTUP}

Penetapan sebuah desa sebagai desa wirausaha dilakukan melalui assessment potensi wilayah, penyesuaian dengan harapan masyarakat dan dengan kebijakan pemerintah. Desa Gunung Malang cocok untuk pengembangan desa wirausaha di Kecamatan Tenjolaya karena pertimbangan sebagai berikut:

1. Memiliki pelaku UMKM yang banyak dengan sumber bahan baku dari desa sendiri. 
2. Berlokasi di wilayah yang memiliki potensi tinggi di sektor pariwisata. Desa Gunung Malang berlokasi di kawasan Gunung Salak Endah dan dekat dengan beberapa destinasi wisata alam seperti Curug Nangka dan Curug Luhur.

3. Memiliki infrastruktur yang baik, terutama jalan yang relatif baik, ketersediaan energi listrik dan sumber air bersih.

4. Memiliki jalur trayek angkutan kota yang langsung terhubung ke Kota Bogor.

Adapun komoditas yang layak dikembangkan sebagai ikon desa wirausaha di Gunung Malang adalah produk hasil pengolahan bambu, seperti tusukan sate, boboko, tampah, dan lain-lain. Adapun yang menjadi pertimbangannya adalah sebagai berikut :

1. Memiliki jumlah pengrajin pengolahan bambu yang banyak.

2. Sumber bahan baku berasal dari desa sendiri sehingga mampu menghasilkan nilai tambah.

3. Produk pengolahan bambu masih dapat dikembangkan menjadi produk yang bernilai tinggi.

Program jangka pendek yang direkomendasikan adalah (1) Pelatihan untuk para pengrajin pengolahan bambu untuk meningkatkan kualitas produk sehingga lebih menarik dan bersaing, (2) Pemberian bantuan peralatan kerja yang sesuai dengan kebutuhan untuk peningkatan kualitas produk. Mengintegrasikan program pengembangan desa wirausaha dengan program desa wisata. Berkaitan dengan program jangka menengah (5 tahun) direkomendasikan untuk mengimplementasikan strategi yang telah disusun.

\section{DAFTAR PUSTAKA}

Drucker, P.F. 1996. Konsep Kewirausahaan Era Globalisasi. Erlangga: Jakarta. Terjemahan

Geoffrey, G. Meredith, et. Al. (1996). Kewirausahaan Teori Dan Praktek. Jakarta: PT. Pustaka Binaman Presindo.

Joko Untoro \& Tim Guru Indonesia. 2010. Buku Pintar Pelajaran SMA/MA IPS. Wahyu Media. Jakarta

Ronald Melicher, J. Leach. 2011.

Entrepreuneurial Finance. SouthWestern College Pub

Rustiadi, Ernan; Saefulhakim, Sunsun dan Dyah R. Panuju, 2011. Perencanaan dan Pengembangan Wilayah. Crestpent Pres dan Yayasan Pustaka Obor Indonesia, Jakarta.

Soehartono, Irawan. 2006. Metode Penelitian Sosial: Suatu Teknik Penelitian Bidang Ilmu Kesejahteraan. Bandung: PT. Remaja Rosdakarya

Widjajani, Arnia Fajarwati, Elly Retnaningrum. 2015. Model Sistem Pembangunan Kewirausahaan Desa Sebagai Sarana Untuk Meningkatkan Kesejahteraan Masyarakat Desa. Sosiohumanitas, XVII (2) Agustus 2015

https://www.pengertian.website/pengertiankeewirausahaan 